\title{
MOTIVASI BELAJAR KIMIA TERHADAP KEMAMPUAN KOGNITIF PESERTA DIDIK PADA MATERI SISTEM KOLOID
}

\author{
Maria Lucia Tuminah ${ }^{1)}$; Christiana Niken Larasati $^{2)}$; Murtihapsari $^{\text {3) }}$ \\ ${ }^{1)}$ Jurusan Pendidikan Kimia UNIPA,MANOKWARI; luciamaria45444@gmail.com \\ ${ }^{2)}$ Jurusan Pendidikan Kimia UNIPA,MANOKWARI; c.larasati@unipa.ac.id \\ ${ }^{3)}$ Jurusan Pendidikan Kimia UNIPA, MANOKWARI; murtihapsari.kadarusman@gmail.com
}

\begin{abstract}
Education can be created through an active learning atmosphere in developing the self-potential of students to have religious spiritual strength, self-control, personality, intelligence, noble character, and skills needed by themselves, society, nation and state. This study aims to determine the influence and relationship between motivation to learn chemistry on cognitive learning outcomes of students at SMA Negeri 1 Manokwari on colloidal system material. The research method used is a quantitative experiment with an associative approach. This research design used pre-experimental design in the form of One-Shot Case Study. The sampling technique in this study used the Non Probability Sampling Technique, with Purposive Sampling. The samples used were students. Data collection instruments included a questionnaire on motivation to learn chemistry and tests of cognitive learning outcomes. The results showed that there was a significant influence between the motivation to learn chemistry on students' cognitive learning outcomes, which was indicated by the significance value obtained from the simple linear regression test and the correlation test, namely 0.0001 and the $R$ Square value of $33 \%$. and there is a positive relationship between motivation to learn chemistry on cognitive learning outcomes of students.
\end{abstract}

Keywords:Learning Motivation; Learning,Cognitive Learning Outcomes; and Colloidal System

\begin{abstract}
ABSTRAK
Pendidikan dapat tercipta melalui suasana belajar yang aktif dalam mengembangkan potensi diri peserta didik untuk memiliki kekuatan spiritual keagamaan, pengendalian diri, kepribadian, kecerdasan, akhlak mulia, serta keterampilan yang diperlukan dirinya, masyarakat, bangsa dan negara. Penelitian ini bertujuan untuk mengetahui pengaruh dan hubungan antara motivasi belajar kimia terhadap kemampuan kognitif peserta didik di SMA Negeri 1 Manokwari pada materi sistem koloid. Metode penelitian yang digunakan adalah quantitaif eksperimen dengan pendekatan asosiatif. Desain yang digunakan dalam penelitian adalah pre-experimental design dengan bentuk One-Shot Case Study. Teknik pengambilan sampel dalam penelitian ini menggunakan Teknik Non Pobability Sampling, dengan Purposive Sampling. Sampel yang digunakan yaitu Peserta Didik kelas. Instrumen pengumpulan data dalam penelitian ini adalah angket motivasi belajar kimia dan tes kemampuan kognitif. Hasil penelitian menunjukkan bahwa terdapat pengaruh yang signifikan antara motivasi belajar kimia terhadap kemampuan kognitif peserta didik, dimana ditunjukkan dengan nilai signifikansi yang didapat dari uji regresi linier sederhana dan uji korelasi yaitu sebesar 0,0001 dan nilai R Square sebesar $33 \%$. dan terdapat hubungan yang positif antara motivasi belajar kimia terhadap kemampuan kognitif peserta didik.
\end{abstract}

Kata Kunci: Motivasi Belajar, Belajar; Kemampuan Kognitif; dan Sistem Koloid 


\section{PENDAHULUAN}

Seiring dengan perkembangan berbagai bidang ilmu pengetahuan dan teknologi khususnya di bidang Pendidikan, maka perlu adanya perhatian khusus dari semua elemen baik sekolah, orangtua, masyarakat maupun pemerintah. Perkembangan ilmu pengetahuan dan teknologi telah mengalami kemajuan yang sangat pesat terutama di bidang pendidikan. Hal tersebut sangat menuntut pada kemajuan dalam sistem pendidikan. Pendidikan yang baik akan menghasilkan Sumber Daya Manusia yang berkualitas sehingga diharapkan berguna bagi lingkungan sekitarnya.

Kondisi pendidikan harus di dukung oleh suasana belajar dan proses pembelajaran yang baik agar peserta didik secara aktif mengembangkan potensi dirinya untuk memiliki kekuatan spiritual keagamaan, pengendalian diri, kepribadian, kecerdasan, akhlak mulia, serta keterampilan yang diperlukan dirinya. Pencapaian pendidikan yang berkualitas diperlukan berbagai perangkat yang menunjang, diantaranya kurikulum (Depdiknas, 2003 :3).

Kurikulum merupakan seperangkat rencana dan pengaturan mengenai tujuan, isi, bahan pelajaran serta cara yang digunakan sebagai pedoman penyelenggaraan kegiatan pembelajaran untuk mencapai tujuan pendidikan tertentu (Kemendikbud, 2013). Kurikulum ini akan diberikan oleh penyelenggara pendidikan yang berisi rancangan pelajaran yang akan diberikan kepada peserta didik dalam satu periode jenjang pendidikan. Pemerintah mengadakan pembaharuan kurikulum yang berkesinambungan. Kurikulum yang digunakan oleh pemerintah saat ini adalah kurikulum 2013. Kurikulum 2013 merupakan kurikulum yang berbasis karakter dan kompetensi, tidak hanya menekankan kepada penguasaan kompetensi peserta didik, melainkan juga pembentukan sikap, keterampilan, serta pengetahuan. Keberhasilan pendidikan tergantung dari perubahan kurikulum yang dilakukan oleh suatu instansi. Salah satunya keberhasilan pendidikan erat kaitannya dengan seorang guru, sebab guru secara langsung mempengaruhi dalam membina dan mengembangkan kemampuan peserta didik dalam proses pembelajaran (Mulyasa, 2013: 163). Selain itu, pembelajaran berlangsung dalam kegiatan yang bersifat interaktif dan komunikatif antara pendidik (guru) dengan peserta didik, sumber belajar dan lingkungan. Suatu kondisi belajar yang baik terjadi pada peserta didik, baik di kelas maupun di luar kelas, yang dihadiri oleh seorang guru secara fisik maupun tidak, dengan tujuan untuk mengasah kompetensinya (Zinal Arifin 2014:10). Pembelajaran harus dijalankan dengan efektif dan efisien sesuai perkembangan ilmu pengetahuan, teknologi dan sains 
Jurnal IImu Pendidikan Indonesia 9 (2) : 106 - 114 | 108

dimana ditekankan dalam penguasaan pengetahuan secara keseluruhan, salah satunya pembelajaran IPA khususnya mata pelajaran kimia.

Ilmu kimia adalah salah satu cabang dari ilmu pengetahuan alam (IPA) yang mempelajari struktur, dan sifat materi (zat), perubahan materi (zat) dan energi yang menyertai perubahan tersebut (Sudarmo 2013:5). Berdasarkan hasil observasi yang dilakukan pada Oktober 2020 di SMA Negeri 1 Manokwari terdapat beberapa masalah dalam kemampuan peserta didik diantaranya: rendahnya motivasi peserta didik dalam mengikuti pelajaran kimia, kesulitan peserta didik dalam memahami materi, masih ada peserta didik yang kurang aktif, kegiatan belajar mengajar yang dilakukan oleh guru kurang bervariasi, kurangnya dorongan atau perhatian khusus pada saat proses pembelajaran, sering tidak masuk sekolah, tidak mengerjakan tugas yang diberikan oleh guru, serta peserta didik memilih bercerita sendiri dan mengabaikan penjelasan guru. Salah satu masalah yang akan dikaji yaitu motivasi belajar dari peserta didik dipengaruhi oleh dua faktor yaitu faktor internal atau dari dalam peserta didik itu sendiri misalnya suasana peserta didik yang kurang baik, tidak adanya kemauan dari dalam diri peserta didik untuk belajar dengan alasan tidak menyenangi pelajaran kimia. Faktor eksternal atau dari luar peserta didik yaitu dari faktor lingkungan keluarga. Dimana kurang mendapat perhatian dari kedua orang tua karena sibuk bekerja. Kondisi ini yang membuat kemampuan peserta didik kurang memuaskan pada akhir pembelajaran khususnya untuk materi sistem koloid, dengan kriteria ketuntasan minimum (KKM) yang diterapkan untuk mata pelajaran kimia di SMA Negeri 1 Manokwari yaitu 75.

Berdasarkan latar belakang tersebut, telah dilakukan penelitian dengan Judul Motivasi Belajar Kimia Terhadap Kemampuan Kognitif Peserta Didik Pada Materi Sistem Koloid peserta didik kelas XI IPA 8 pada materi Sistem Koloid di SMA Negeri 1 Manokwari.

Berdasarkan tujuan di atas, maka penelitian ini perlu dikaji karena belum pernah dilakukan terkait penelitian eksperimen mengenai motivasi belajar terhadap kemampuan peserta didik kelas XI IPA 8 pada materi Sistem Koloid di SMA Negeri 1 Manokwari.

\section{METODE PENELITIAN}

Penelitian ini dilaksanakan dengan menggunakan metode penelitian kuantitatif eksperimen dengan pendekatan Asosiatif. Pendekatan asosiatif ini merupakan metode penelitian yang bersifat menanyakan hubungan antara dua variabel atau lebih (Sugiyono, 2014:36). Dalam penelitian ini desain penelitian yang digunakan adalah Pre-experimental Design.. Hal ini 
disebabkan tidak adanya variabel kontrol, dan sampel tidak pilih secara random. (Sugiyono, 2014:74).Populasi dalam penelitian ini adalah seluruh peserta didik kelas XI IPA di SMA Negeri 1 Manokwari yang berjumlah 300 (tiga ratus) peserta didik. Sampel pada penelitian ini adalah peserta didik kelas XI IPA 8 SMA Negeri 1 Manokwari dengan total 29 (dua puluh sembilan) peserta didik, Teknik pengambilan sampel dalam penelitian adalah dengan menggunakan Nonprobability Sampling dengan Teknik purposive sampling atau pengambilan sampel dengan tujuan dan pertimbangan tertentu. (Sugiyono, 2014 :85). Teknik pengumpulan data yang dilakukan dalam penelitian ini menggunakan dua teknik yaitu teknik tes dan teknik non tes. Dimana untuk teknik tes ini berupa kemampuan koginif melalui nilai quis peserta didik. Untuk teknik non tes berupa observasi, wawancara, angket dan dokumentasi. Berikut ini adalah penjelasan dari teknik tes dan teknik non tes yang digunakan dalam penelitian:

1. Observasi

Observasi atau pengamatan dilakukan dengan cara pengamatan langsung yang berarti pengumpulan data dapat dilihat di tempat sekolah tersebut dilakukan.

2. Wawancara

Wawancara yang digunakan dalam mengumpulkan data peneliti menggunakan wawancara tidak terstruktur. (Sugiyono, 2014:140).

3. Tes kemampuan

Tes kemampuan kognitif yang digunakan dalam penelitian berupa nilai kuis peserta didik pada materi sistem koloid pada subab sistem koloid dan jenis-jenis koloid.

4. Kuisioner (Angket)

Menurut Sugiyono, 2014:142 Angket merupakan Teknik pengumpulan data dilakukan dengan cara memberi pertanyaan atau pernyataan tertulis kepada responden (Penelitian ini menggunakan angket yang akan diberikan kepada peserta didik secara online agar dapat memberikan informasi mengenai pengaruh motivasi belajar peserta didik kelas XI IPA 8 SMA Negeri 1 Manokwari.

\section{HASIL DAN PEMBAHASAN}

Sebelum mendapatkan hasil, maka peneliti melakukan analisis data deskriptif, analisis statistik inferensial, uji regresi sederhana dan uji korelasi. Analisis data statistic deskriptif adalah statistik yang digunakan untuk menganalisis data dengan cara mendeskripsikan atau menggambarkan data yang telah terkumpul, tanpa membuat kesimpulan yang berlaku untuk umum atau generalisasi (Sugiyono, 2014:147). Sedangkan untuk analisis statistik ferensial merupakan teknik analisis yang digunakan untuk 
menganalisis data sampel dan hasilnya diberlakukan untuk populasi yang jelas, dan teknik pengambilan sampel dari populasi yang dilakukan secara random (Sugiyono,2013). Hasil penelitian ini, sebelum data dianalisis dengan uji prasyarat terlebih dahulu data dilakukan uji analisis deskriptif. Analisis ini digunakan untuk mendapatkan data berupaskor ratarata, skor tertinggi, skor terendah, dan standard deviasi menggunakan software SPSS 26. Setelah dilakukan uji analisis deskriptif, selanjutnya untuk menguji hipotesis hasil data yang diperoleh terlebih dahulu dilakukan uji prasyarat analisis dengan menggunakan uji normalitas. Metode atau teknik yang digunakan untuk uji normalitas pada penelitian ini adalah dengan menggunakan uji KlomogorovSmirnov dengan bantuan program aplikasi SPSS 26. Jika nilai signifikan dari hasil uji Klomogorov- Smirnov > 0.05, maka asumsi normalitas terpenuhi.

\section{Hasil Uji Deskriptif Angket Hasil Kognitif Belajar}

Analisis ini digunakan untuk mendapatkan data berupa skor rata-rata, skor tertinggi, skor terendah, dan standard deviasi dari kemampuan kognitif peserta didik menggunakan software SPSS 26 (Tabel 1):
Tabel 1. Data Hasil Deskriptif Kemampuan Kognitif

\begin{tabular}{lccccc}
\hline & N & \multicolumn{3}{c}{ Deskriptif Statistik } \\
& & Minimum & Maksimum & Mean & $\begin{array}{r}\text { Standar } \\
\text { Deviasi }\end{array}$ \\
& & & & & \\
\hline Kemampuan & 29 & 50 & 96 & 76,86 & 11,85 \\
Valid & 29 & & & & \\
\hline
\end{tabular}

Berdasarkan Tabel1 di atas menunjukkan bahwa nilai minimum pada nilai kuis didapatkan sebesar 50, untuk nilai maksimumnya didapatkan sebesar 96, dan untuk nilai meannya didapatkan sebesar 76,86. Selanjutnya untuk standard deviasi pada kemampuan didapat sebesar 11,85

\section{Hasil Uji Deskriptif Angket Motivasi Belajar Kimia}

Analisisini digunakan untuk mendapatkan data berupa skor rata-rata, skor tertinggi, skor terendah, dan standard deviasi dari kemampuan kognitif peserta didik menggunakan software SPSS 26.

Tabel2. Data Hasil Deskriptif Angket Motivasi Belajar Kimia

\begin{tabular}{lccccc}
\hline & N & \multicolumn{3}{c}{ Deskriptif Statistik } \\
& & Minimum & Maksimum & Mean & $\begin{array}{c}\text { Standar } \\
\text { Deviasi }\end{array}$ \\
& & & & & 11,03 \\
\hline Motivasi & 29 & 86 & 140 & 109,10 & \\
Belajar & & & & & \\
Valid & 29 & & & & \\
\hline
\end{tabular}

Berdasarkan Tabel 2 di atas menunjukkan bahwa nilai minimum pada 
nilai kuis didapatkan sebesar 86, untuk nilai maksimumnya didapatkan sebesar 140, dan untuk nilai meannya didapatkan sebesar 109,10. Selanjutnya untuk standard deviasi pada kemampuan didapat sebesar11.03.

\section{Uji Normalitas Nilai Angket}

Uji prasyarat analisis nilai angket untuk mengetahui normalitas dari angket yang diberikan kepada 29 (dua puluh sembilan).Data hasil uji normalitas nilai angket dapat dilihat pada Tabel 1

Tabel 3. Data Uji Normalitas Angket Motivasi Belajar

\begin{tabular}{llllll}
\hline Data & Statistik & Df & Sig & A & Keterangan \\
\hline Motivasi & 0,10 & 29 & 0,20 & 0,05 & Normal \\
Belajar & & & & & \\
Peserta & & & & & \\
didik & & & & & \\
\hline
\end{tabular}

Berdasarkan Tabel 3 menunjukkan bahwa nilai signifikansi untuk data Motivasi Belajar adalah 0,20, yang berarti lebih besar dari nilai A $(0,05)$, Hal ini sesuai dengan pendapat dari (Widiyanto, 2010) yang menyatakan bahwa jilka nilai signifikansi atau nilai probabilitas > 0,05, maka data terdistribusi normal.

\section{Uji Normalitas Nilai Kemampuan Kognitif}

Nilai kemampuan kognitif yang di uji prasyarat analisis adalah nilai dari 29 (dua puluh sembilan) peserta didik yang mengisi angket motivasi belajar.Data hasil uji normlitas kemampuan kognitif dapat dilihat Tabel.4:
Tabel 4. Data Uji Normalitas Kemampuan Kognitif

\begin{tabular}{llllll}
\hline Data & $\begin{array}{l}\text { Statisti } \\
\mathbf{k}\end{array}$ & $\begin{array}{l}\text { D } \\
\mathbf{f}\end{array}$ & Sig & $\mathbf{A}$ & $\begin{array}{l}\text { Keteranga } \\
\mathbf{n}\end{array}$ \\
\hline $\begin{array}{l}\text { Kemampua } \\
\text { n Kognitif }\end{array}$ & 0,15 & 2 & 0,0 & 0,0 & Normal \\
$\begin{array}{l}\text { Peserta } \\
\text { didik }\end{array}$ & & 9 & 6 & 5 & \\
\hline
\end{tabular}

Berdasarkan Tabel 4. menunjukkan bahwa nilai signifikansi untuk data Motivasi Belajar adalah 0,06 yang berarti lebih besar dari nilai A $(0,05)$, sehingga dapat disimpulkan bahwa data motivasi belajar terdistribusi normal. Hal ini sesuai dengan pendapat dari Widiyanto, 2010), yang menyatakan bahwa jilka nilai signifikansi atau nilai probabilitas $>0.05$ maka data terdistribusi normal. mewakili populasi.

\section{Uji Homogenitas}

Uji homogenitas dalam peneltian ini dilakukan untuk mengetahui dan meyakinkan bahwa sampel atau kelompok data dalam penelitian ini berasal dari populasi yang memiliki varians sama (homogen). Peneliti menggunakan Leneve Test dalam aplikasi SPSS 26 untuk melakukan uji homogenitas. Dasar pengambilan keputusan menurut Budiantara (2017) adalah jika nilai signifikan $\leq 0.05$ maka dikatakan data tidak homogen, dan jika nilai signifikan $\geq$ 0.05 maka dikatakan data homogen. Hasil uji homogenitas dalam penelitian ini dapat dilihat pada Tabel 5: 
Tabel 5. Hasil Uji Homogenitas

\begin{tabular}{llllll}
\hline Data & Df & $\begin{array}{l}\text { Df } \\
\mathbf{1}\end{array}$ & Sig. & A & Keterangan \\
& $\mathbf{2}$ & & & \\
\hline Kemampuan & 3 & 6 & 0,82 & 0,05 & Homogen \\
Kognitif & & & & & \\
\hline
\end{tabular}

Berdasarkan Tabel 5. menunjukkan bahwa nilai sifgnifikan yang diperoleh yaitu sebesar 0,817 yang artinys lebih besar dari 0,05. sehingga dapat dikatakan data dalam penelitian ini adalah homogen. Hal ini sesuai dengan pendapat dari Budiantara (2017), yang menyatakan bahwa jika nilai signifikan > 0,05 maka sampel berasal dari varian yang sama atau dapat dikatakan homogen.

Setelah didapatkan hasil uji prasyarat normal dan homogen maka akan dilaksanakan uji hipotesis I dan II yaitu dengan melakukan uji Regresi Liner Sederhana dan Uji Korelasi.

\section{Uji Regresi Liner sederhana}

Tabel 6. Hasil Uji Regresi Linier Sederhana Motivasi Belajar dan Kemampuan

\begin{tabular}{lccccc}
\hline $\begin{array}{l}\text { Variabe } \\
\text { lbebas }\end{array}$ & $\begin{array}{c}\text { Variabelteri } \\
\text { kat }\end{array}$ & Sig & A & $\begin{array}{c}\mathbf{R} \\
\text { Square }\end{array}$ & Keterangan \\
\hline $\begin{array}{c}\text { MotivasiBe } \\
\text { lajar Kimia }\end{array}$ & $\begin{array}{c}\text { HasilBelajar } \\
\text { Kognitif }\end{array}$ & 0,001 & 0,05 & 0,33 & $\begin{array}{c}\text { Terdapatpe } \\
\text { ngaruh }\end{array}$ \\
\hline
\end{tabular}

Berdasarkan tabel 6 menunjukan bahwa hasil analisis hipotesis pertama diketahui nilai signifikan yang diperolah sebesar 0,001, di mana 0,001 $<0,05$ maka $\mathrm{H}_{0}$ ditolak dan $\mathrm{H}_{1}$ diterima yang berarti ada pengaruh motivasi belajar kimia terhadap kemampuan kognitif peserta didik kelas XI
IPA 8 di SMA Negeri 1 Manokwari pada materi sistem koloid. Pengaruh yang diberikan sebesar 0,33 yang didapatkan dari nilai $R$ Square yaitu $33 \%$. Hal ini ditunjukkan dengan hasil penelitian sebelumnya oleh Irma Nirmayanti (2015) bahwa motivasi belajar kimia berpengaruh terhadap kemampuan dengan ditunjukkan nilai signifikan sebesar 0.04. Jadi nilai siginifikan ini lebih kecil dari 0.05. yang artinya $\mathrm{H}_{0}$ ditolak dan $\mathrm{H}_{1}$ diterima yang berarti ada pengaruh motivasi belajar belajar terhadap kemampuan kognitif peserta didik. Hasil perhitungan koefisien determinasi $\left(\mathrm{R}^{2}\right)$ pada motivasi belajar kimia sebesar 0.33 . Hal ini berarti terdapat pengaruh motivasi belajar kimia terhadap kemampuan kognitif peserta didik sebesar $33 \%$, sehingga dapat disimpulkan bahwa terdapat pengaruh yang signifikan antara motivasi belajar kimia terhadap kemampuan kognitif peserta didik. Setelah dilakukan uji Regresi linear sederhana makan langkah selanjutkan akan melaksanakan persamaan regeresi, yang terdapat didalam tabel 7:

Tabel 7. Data Persamaan Regresi

\begin{tabular}{cccc}
\hline \multicolumn{4}{c}{ Data } \\
& Variabel & & \\
\hline Variabel & terikat & & \\
Bebas & B & & \\
\hline Motivasi & Kemampuan & 30,5 & 1,44 \\
Belajar Kimia & Kognitif & 0 &
\end{tabular}


Berdasarkan persamaan Regresi pada Tabel.7 diperoleh nilai koefisien (a) = 30,50 dan nilai $(b)=1,44$ persamaan uji regresinya adalah sebagai berikut:

$\mathrm{Y}=\mathrm{a}+\mathrm{bX}$

$\mathrm{Y}=30.50+1,44 \mathrm{X}$

$\mathrm{Y}=30,50+1,44$

Persamaan regresi linear sederhana tersebut dapat disimpulkan bahwa, jika motivasi belajar peserta didik setiap penambahan $1 \%$ akan terjadi nilai motivasi belajar yang bertambah sebesar 1,44 yang artinya koefisien

regresi tersebut bernilai positif. Berdasarkan persamaan regresi maka akan memperkuat bahwa adanya pengaruh motivasi belajar kimia terhadap kemampuan koginitif peserta didik. Hal ini sesuai dengan Sudjana (2015) yang menyatakan bahwa koefisien b dinamakan koefisien arah regresi linear dan menyatakan perubahan rata-rata variabel $\mathrm{Y}$ untuk setiap perubahan variabel $\mathrm{X}$ sebesar satu unit. Perubahan ini merupakan pertambahan apabila $b$ bertanda negatif dan penurunan atau pengurangan bertanda positif.

\section{Uji Korelasi}

Tabel 8. Hasil Uji Korelasi Motivasi

\begin{tabular}{cccccc}
\hline $\begin{array}{c}\text { Variabel } \\
\text { Bebas }\end{array}$ & $\begin{array}{c}\text { Variabe } \\
\text { l terikat }\end{array}$ & Sig & A & $\begin{array}{c}\text { Persen } \\
\text { Korelasi }\end{array}$ & $\begin{array}{c}\text { Ketera } \\
\text { ngan }\end{array}$ \\
\hline $\begin{array}{c}\text { Motivasi } \\
\text { Belajar } \\
\text { Kimia }\end{array}$ & $\begin{array}{c}\text { Kemam } \\
\text { puan } \\
\text { Kognitif }\end{array}$ & $\begin{array}{c}0,00 \\
1\end{array}$ & $\begin{array}{c}0,0 \\
5\end{array}$ & 1,00 & $\begin{array}{c}\text { Sangat } \\
\text { tinggi }\end{array}$ \\
\hline
\end{tabular}

Berdasarkan Tabel 8, hasil analisis hipotesis kedua didapatkan nilai sig sebesar 0,001 , di mana $0,001<0,05$ sehingga dapat diartikan $\mathrm{H}_{0}$ ditolak dan $\mathrm{H}_{1}$ diterima yang berarti ada hubungan antara motivasi belajar kimia dan kemampuan kognitif peserta didik di SMA Negeri 1 Manokwari. Berdasarkan nilai $\mathrm{R}$ yang dihasilkan sebesar 1 yang berarti bahwa motivasi belajar kimia dan kemampuan kognitif kimia saling berhubungan atau berkorelasi. Menurut Arikunto (2002), terdapat beberapa kategori untuk nilai interpretasi korelasi yaitu sangat tinggi $(0,8$ $-1,0)$, Tinggi $(0,6-0,8)$, cukup $(0,4-0,6)$, rendah $(0,2-0,4)$, dan sangat rendah $(0,0-$ $0,2)$, sehingga hasil yang diperoleh dari penelitian ini termasuk dalam kategori sangat tinggi yang berarti ada hubungan yang positif. Hal ini sesuai dengan pendapat Sugiyono (2016) yang menyatakan bahwa nilai positif negatif menunjukkan hubungan yang baik dimana jika kenaikan variabel $\mathrm{X}$ diikuti kenaikan variabel Y, maka hubungan memiliki arah positif. Sehingga dari pernyataan diatas dapat disimpulkan bahwa terdapat hubungan yang signifikan antara motivasi belajar kimia terhadap kemampuan kognitif peserta didik kelas XI IPA 8 di SMA Negeri 1 Manokwari pada materi sistem koloid. 


\section{SIMPULAN DAN SARAN \\ SIMPULAN}

Motivasi belajar kimia berpengaruh terhadap kemampuan kognitif peserta didik pada materi Koloid.

\section{SARAN}

Guru harus memperhatikan motivasi bagi peserta didik dalam pembelajaran kimia.

\section{UCAPAN TERIMA KASIH}

Kepala Sekolah SMA Negeri 1 Manokwari yang telah bekerjasama dengan Jurusan Pendidikan Kimia Universitas Negeri Papua dalam melaksanakan penelitan ini.

\section{DAFTAR PUSTAKA}

Arikunto. Metode Penelitian Kualitatif. Jakarta: Bumi Aksara. 2002;

Budiantara, M. (2017). Dasar-dasar. Statistik Penelitian. Yogyakarta: Sibuku Media;

Depdiknas. Undang-undang RI No.20 Tahun 2003 Tentang Sistem Pendidikan Nasional. 2003;
Mulyasa. Kurikulum Berbasis Kompetensi. Bandung: PT Remaja Rosdakarya. hal. 16. 2013;

Nirmayanti, . "Pengaruh Pendekatan Pembelajaran Dan Motivasi Belajar terhadap Kemampuan Kimia Peserta Didik Kelas XI IPA SMAN 12 Bulu Kumba”. Jurnal Penelitian.2015;

Sudarmo, U. Seri Mode Simple (SMS) Kimia SMA. Jakarta: Rineka Cipta. 2013: hal:5

Sudjana, N. Penilaian Kemampuan Mengajar. Bandung: PT Remaja Rodaskarya. 2008

Sugiyono. Metode Penelitian Kuantitatif Kualitatif dan R\&D. Bandung: Alfabeta. 2016

Sugiyono. Metode Penelitian Kuantitatif, Kualitatif dan R\&D. Bandung: Alfabeta. 2017

Sugiyono. Metode Penelitian Kuantitatif, Kualitatif dan R\&D. Bandung: Alfabeta. 2018

Widiyanto, Joko. SPSS For WindowsUntuk Analisis Data Statistik dan Penelitian. Surabaya: BP- FKIP UMS.2010

Zinal, Arifin. Evaluasi Pembelajaran. Bandung: PT Dosdakarya. 2014. 